\title{
Impacto da formação médica sobre a consciência de estudantes de medicina na Unicamp
}

\author{
Gastão W. S. Campos (PQ), Gabriel F. Barros (IC)
}

\begin{abstract}
Resumo
As transformações do mundo do trabalho na sociedade atual exigem novas características da educação para qualificação da força de trabalho. Com a flexibilização do trabalho a partir da década de 70 , e a substituição do trabalho vivo pelo trabalho morto, torna-se ainda mais evidente a importância da formação ideológica dos trabalhadores. Diante dessas transformações, é mister o entendimento de como se dá a mudança de consciência dos estudantes de medicina ao longo de sua graduação.
\end{abstract}

Palavras Chave: Educação médica, trabalho em saúde, consciência.

\section{Introdução}

Entendendo que o modo de produção é constituído pela unidade das forças produtivas e das relações de produção, podemos concluir que a sobrevivência e desenvolvimento de uma formação social depende da reprodução de suas forças produtivas e da reprodução de suas relações de produção. A reprodução da força de trabalho, por sua vez, envolve aspectos necessários à vida humana - alimentação, vestimenta, moradia, saúde etc.- mas também a qualificação técnica e ideológica para a concretização da força de trabalho em trabalho.

Com o desenvolvimento do capitalismo, há, a partir da década de 70 , a transição entre 0 "regime de acumulação taylorista-fordista" para o "regime de acumulação flexível". Com essa modificação no mundo trabalho, surgem novas necessidades para a formação da força de trabalho. Diante desse panorama, portanto, tornase mister o entendimento de como se dá a transformação de consciência do estudante de medicina ao longo de sua qualificação para 0 trabalho, ao longo da sua educação. A relação dos estudantes de medicina entre si mesmos, com o curso e com o trabalho médico ao longo da graduação, determina a consciência que terão, enquanto trabalhadores, de si mesmos e do trabalho que desempenham. Como se dá essa transformação ao longo do curso? É possível identificá-la? Qual o caráter dessa transformação? Em qual período do curso ela é mais intensa? Quais são os elementos do curso que determinam essas transformações? São a essas perguntas que o presente trabalho se propõe a dar elementos.

\section{Resultados e Discussão}

A partir do referencial bibliográfico estudado, elaborou-se um questionário para ser aplicado aos estudantes, que em seu pré-teste, levou, em média,10,75 min para ser respondido, sem alterações significativas a serem feitas no questionário. A aplicação dos questionários ainda não foi finalizada.

\section{Conclusões}

Como a aplicação do questionário ainda não foi finalizada, não há ainda conclusões do trabalho.

\section{Agradecimentos}

Agradeço ao meu orientador, Prof. Dr. Gastão pela paciência e contribuições ao trabalho. Agradeço também ao SAE/UNICAMP pelo fomento ao projeto

-Albuquerque, GSC. As determinações do capital sobre a formação
do trabalhador na saúde: um estudo sobre reformulações
curriculares em dois cursos de medicina do Paraná. Tese
(Doutorado) - Setor de Educação, Universidade Federal do Paraná, 2009.

-Almeida, MR. A relação entre consciência individual e a consciência de classe: uma análise das contribuições de Vigotski sobre a consciência da classe trabalhadora. Dissertação (Mestrado)

- Setor de Educação, Universidade Federal do Paraná, 2008.

-Damasceno, BP. In: Desenvolvimento das funções corticais superiores. Neurologia do desenvolvimento da criança; Revinter, 2006.

-Gomes, RM. As mudanças no mundo do trabalho e a qualificação do trabalho em saúde. Dissertação (Mestrado) - Setor de Educação, Universidade Federal do Paraná, 2007.

-MARX, K. Prefácio à Crítica da Economia Política. [1859]

Marxists Internet Archive, abr. 2014. Disponível em:

<http://www.marxists.org/portugues/marx/1859/01/prefacio_crit_ec o_pol.htm> Acesso em: 04abr. 2014.

-MARX, K. O Capital: crítica da economia política: livro 1. $26^{a}$ edição. Rio de Janeiro: Civilização Brasileira, 2006. 